\title{
Designing and Building an Information System for a Higher Education Institution
}

\author{
Ljiljana Ružić-Dimitrijević and Božo Nikolić \\ The Higher Education Technical School of Professional Studies, \\ Novi Sad, Serbia
}

ljaga@eunet.yu; direktor@vtsns.edu.yu

\begin{abstract}
The paper describes the initiative of the management of a higher education institution to design and realize an Information System (IS) in order to implement new study rules for new study programmes that are in agreement with the Bologna Declaration.

The authors based their work on the common theory about projecting ISs, but with focus on expected practical results. The goal is to achieve better organization in our Institution and necessary informing about conditions and regulations of studies. This information has to be supplied to both students and faculty staff.

Knowing the old study system and its differences with respect to the new one, authors attempted to create a prototype for a new IS that incorporates strict rules regarding enrolment into study years, course selection, and taking exams. In this way the IS will resolve many issues and questions for students and staff alike.
\end{abstract}

Keywords: projecting, information system, study rules.

\section{Introduction}

An IS implemented within an organization has a role of improving its effectiveness and efficiency. Individuality of the organization, its work systems, and its development determine the extent to which these two intentions are accomplished.

IS applications deal with the progress and management of an organization's IT infrastructure. An information system holds processes, data records and activities that process the data and information in the organization. The focus is on why and how technology can be put into best use to serve the information flow within an organization.

ISs are developed along a time axis known as the system life cycle. Principle stages of the life cycle are initiation, analysis of the existing situation, applicability study, and definition of the

Material published as part of this publication, either on-line or in print, is copyrighted by the Informing Science Institute. Permission to make digital or paper copy of part or all of these works for personal or classroom use is granted without fee provided that the copies are not made or distributed for profit or commercial advantage AND that copies 1) bear this notice in full and 2) give the full citation on the first page. It is permissible to abstract these works so long as credit is given. To copy in all other cases or to republish or to post on a server or to redistribute to lists requires specific permission and payment of a fee. Contact Publisher@InformingScience.org to request redistribution permission. new system, design, development, implementation, and maintenance. The system definition stage summarizes user needs and comprises the basis for system design and development. This stage is a key stage and, therefore, has to involve all significant issues related to user needs.

IS specification allows controlling and supervising all its elements. Besides the 
specification of the elements, creating the link between the specification of the elements and the authentic elements is essential. In this way, many development problems can be avoided.

Object Oriented Design using Prototype Methodology (OODPM) focuses on system planning and studying the current condition. Initially, it is a study of the current situation in order to identify the needs, and then to come to the business specifications for the new system.

Activities required for the system are identified as a set of data and processes linked and dealing with a defined subject. (Demeyer \& Bosh, 1998).

The process of conducting a business analysis in order to specify the goals of the organization, defines a set of operations that need to be performed. It is followed by defining data sets, events and processes in which information has operations performed upon it (Lindsay, 2006).

Analysis consists of several steps: understanding system organization and which changes are necessary; identifying the roles, goals and assessments for business; and defining information requirements due to achieve predicted roles. Management has to be involved on planning and projecting IS (Prince, 1971).

IT (information technology) is a strategic resource. Managers have to recognize this. They need only basic computer knowledge, but their responsibility is the efficient usage of IT. Redesigning of a business process cannot be properly done only by using technology - it needs to involve managers. Managers have to decide about involving IT into their business processes, because they know the business needs and how to utilize technology for their achievement (Gates, 2001).

Our Advanced Technical School was accredited as The School of Professional Higher Education in 2007. For this purpose the School's management during the last two years prepared, defined, and performed changes in curricula and syllabi for all study programs according to the Bologna Declaration. Following the legal recommendations and fulfilling the required standards set by the Serbian Ministry of Education, we established new studying rules. Accordingly, our existing information system needed a change.

There are several faculty members with a rich experience in that kind of business and therefore, they have been involved in system planning. In the beginning, there were faculty members who resisted working daily on PCs, but now they are asking the management team for a more useful IS.

There were many challenges while defining the new information system. The law is slightly soft; the Ministry of Education offered very limited help, and we started our work with a large amount of undefined facts and rules. However, we believe that so far no educational institution in the country has completed a new IS which is in full compliance with the new study rules.

At that time the Dean and the Pro-dean for teaching had the deepest insight into the new education process rules therefore, they decided to prepare the IS project. This project encompasses all processes concerning studying, from application to graduation.

The intention was to make a project that will serve as a prototype for producing the IS. According to this project, a team of our second year IT students would create the IS as a project within the subject Software Engineering, supervised by lecturers from this area.

\section{Educational Processes at Higher Education Institution}

Among the main processes in our institution presented in (Lovrekovic, RuzicDimitrijevic, \& Nikolic, 2007), in this paper we are focusing on the following components of the overall process of studying: 
- Students' enrolment

- Teaching

- Students assessing

- Tuition fee charges

- Issuing of certificates, degrees and students record

To examine the current state and set the objectives that we wish to achieve, these processes should be specified in detail (Davenport, 1997; Drucker, 1999b; Koulopoulos, 1997). The same applies to a new process.

In order to reengineer a process, we have to compare AsIs model (current state) with ToBe model (state that we would like) (Amberg, 1996).

In our case, the processes are the same, but conditions for their conducting have been changed due to modified study rules.

\section{New Study Rules}

All our study programmes last three academic years with allocated credit of 180 ESTC (European System Transfer Credit). In the curriculum, there are obligatory subjects out of parent study programme and two or three elective subjects, which students can choose from other study programmes at the School. The ratio between obligatory and elective courses is $85 \%$ to $15 \%$. The electives that attract a lot of students require more groups.

All subjects in the final semester are electives chosen out of professional subjects within the parent study programme. Since we are the School of Professional Higher Education, it is essential to include practical work as an important part of the education. This semester involves practical assignments and work experience. The students acquire work experience in companies dealing with their study area.

For all subjects, teaching is delivered on a weekly basis during a semester or through block system (at weekends) for students who are employed

Every subject has an allocated credit and the sum is 60 ESTC for one study year. Students enrolling to a school year choose obligatory and elective subjects from the appropriate study programme for that year. Students financed by the government must apply for subjects carrying at least 60 ESTC, and self-financed students apply for at least 37 ESTC. Self-financed students may pay tuition fee in two installments at the beginning of each semester, but they have to choose subjects carrying at least 19 ESTC in the first semester and the remaining in the second semester.

The students can take an examination for each subject three times in one academic year, in the exam periods defined in advance in the School calendar.

If the government-financed student does not gain $60 \mathrm{ESTC}$ in an academic year, he/she continues studying as self-financed. Government can finance a self-financed student if he/she attains 60 ESTC in an academic year. The number of government-financed students for each study group is defined by the Government, and, for the purpose of co-financing awards, students need to be ranked by their marks in the previous study years.

The enrolment in an academic year is in October while enrolment of a study year can be in October and February, at the beginning of each semester. The academic year always begins on October 1 and finishes on September 30 the following year. For each student the study year begins the moment he/she gathers the required number of credits for the enrollment of the next year. 
The self-financed student can enroll into the second study year if he/she passes the first year subjects carrying at least 37 ESTC, while for the enrollment into the third study year, he/she needs to achieve at least 97 ESTC from the first and second year subjects.

If a student enrolls the next study year, he/she must choose the remaining subjects of the previous study years and all the subjects from the enrolled study year. A student who enrolls the next academic year, but the same study year, has to choose the failed subjects and a few subjects from the next study year so that he/she enrolls a total of 37 ESTC.

The curriculum and syllabuses for the final semester are very specific and unique. In the sixth semester, the titles of the subjects are identical for all study groups: Practical Exercises, Engineering Work Experience $1 \& 2$, and The Final Examination. However, the content is specific for each study programme - as the Work Experience is linked with professional subjects within each parent study programme, and there are special conditions for choosing those subjects.

The theoretical parts of Practical Exercises are taught at the School but the exercises are conducted at specific companies. This is performed in one day per week while for the Work Experience $1 \& 2$ the students go to work in the chosen company four days a week. The business orientation of the company must be related to the students' study area.

The Final Examination is the graduation thesis. At the end of their studies, the students define a topic for it. The graduation thesis consists of a theoretical and experimental part. During the practical work in the last semester, the students can collect data to be used for their graduation thesis.

Because of such a structure of the sixth semester, the students can choose subjects Engineering Work Experience 1\&2 and Final Examination only if they have less then three uncompleted subjects from the previous five semesters. Practical Exercises can be chosen in the second year if it is needed to fill up 37 ESTC, but only in the even semester, because of period contracting with partner companies.

\section{System Analysis}

System analysis focuses on the real system and its model, information system. It is performed through three units:

- Identifying and real system analysis,

- Data and information flow analysis,

- Identifying the information needs.

\section{Identifying and Real System Analysis}

The goal of this unit in the system analysis is to recognize all structural components and the overall structure of the organization. The structure organization consists of the real system, the administration system, and the management system. In addition, there is a need for identification of relevant subjects and system distribution.

There is a structure organization presented as an organization units set. At the first level, there are the Finance Department, the Common Services, and the Departmental Administrator (Figure 1). The second level consists of department units subordinated to the Administrator. Each department has several study programmes as sublevels. 


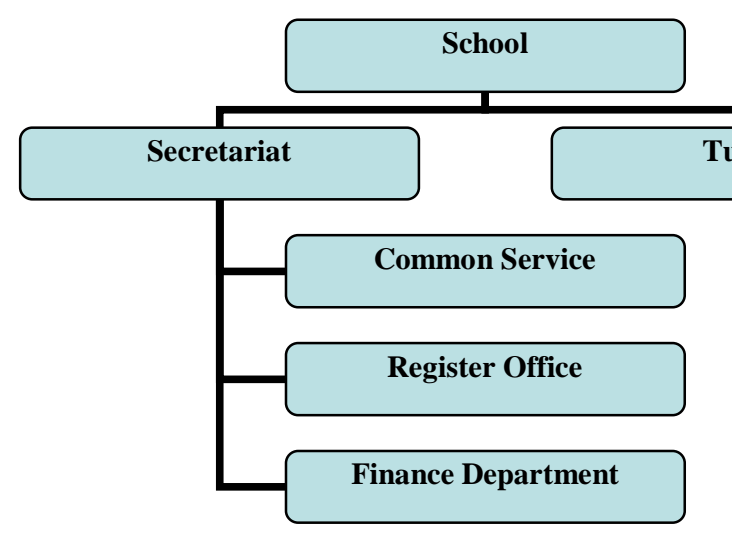

uition

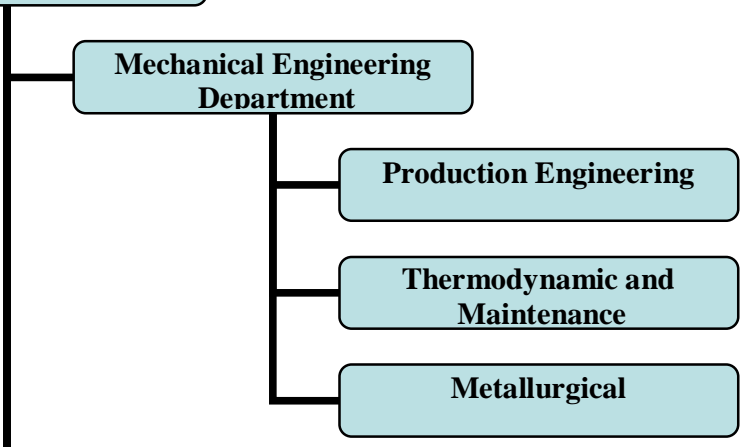

Protection Department

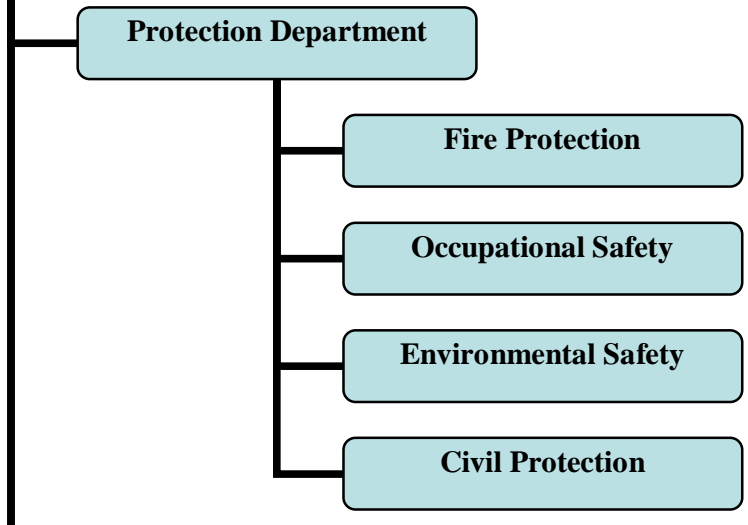

Graphical Department

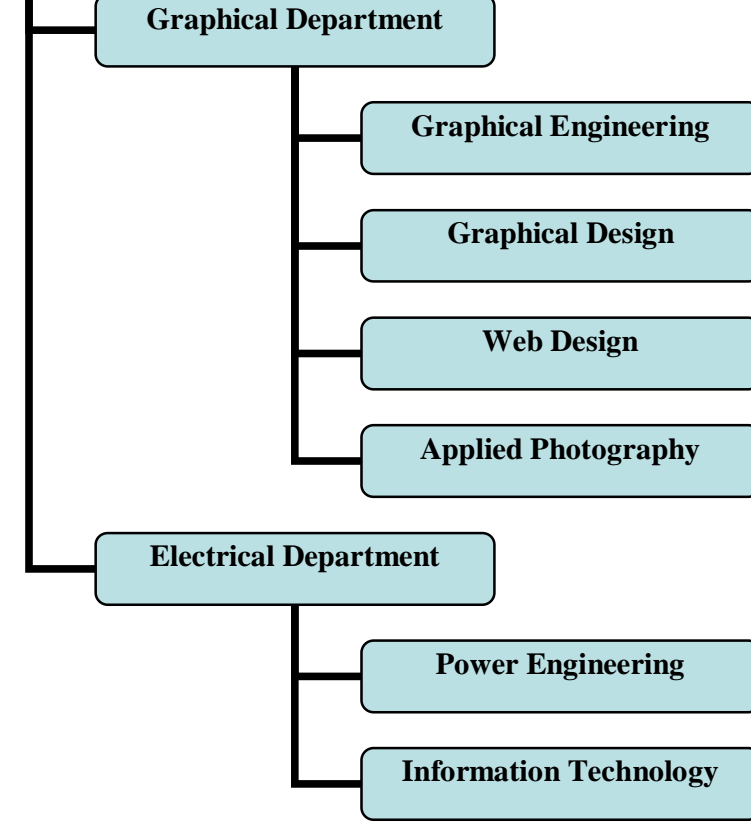

Figure 1: School organization chart 


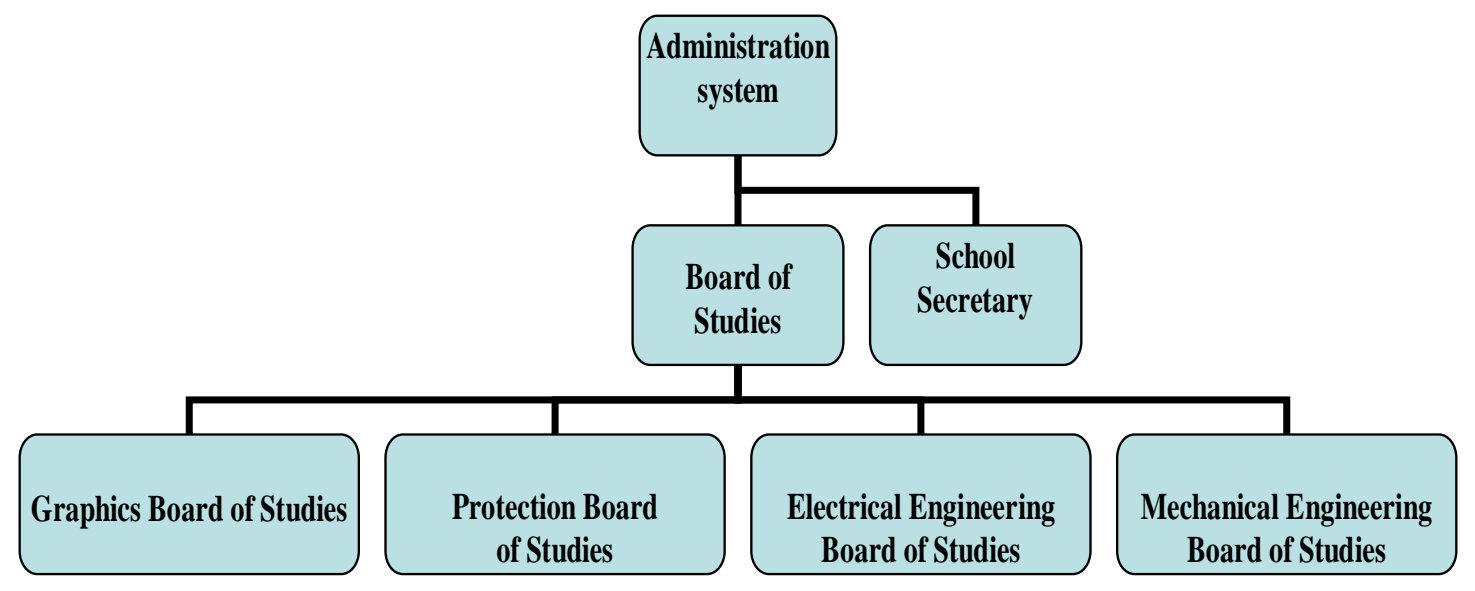

Figure 2: Administration organization chart

Administration system (Figure 2) consists of the School Board of Studies, departmental Boards of studies, and the School Secretary.

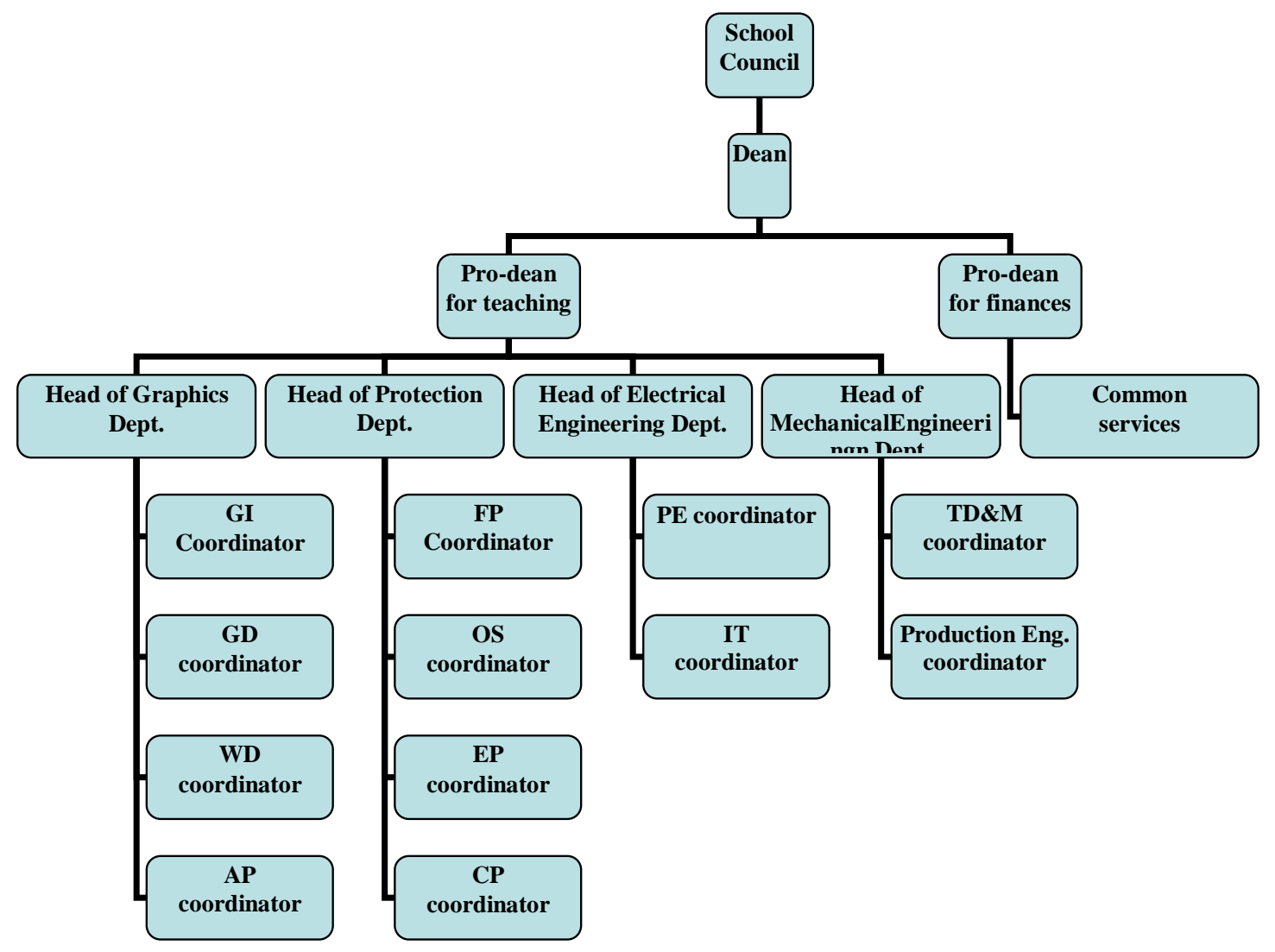

Figure 3: Management organization chart 
Constituents of the management system are the School council, Dean, Pro-deans (teaching and finances), Heads of Departments, and coordinators of each study programme (Figure 3).

Relevant subjects are the students, the faculty staff, the support staff and the management. Students and lecturers give the input data and support staff process these data in order to provide outputs to the students (student record, certifications, etc.), to the lecturers (student lists for current courses, lists of exams) and to the management (reports, statistics, etc.).

The information system is distributed among several locations in one building.

\section{Data and Information Flow Analysis}

IS integrates information sources and data, as well as the flow of information. Concerning data and information flow, various methods and techniques can be used. There are conventional (manual) and automated methods - software tools, CASE tools (Computer Added Software Engineering).

IBM developed BSP (business system planning) method in the 1980's. BSP is a top-down strategy of planning and bottom-up for implementation. IS architecture is designed based on the business processes and data that are specific resources in the system. Management should be involved in the IS planning and business goals should be supported by IS goals. Besides strategy of planning, this method can be used for data and information flow analysis.

Although there are several newer methods (SADT - Structured Analysis and Design Technique, IDEF - Integrated Definition Methods, SSA - Structural System Analysis), we have chosen the BSP method, as we consider it to be simple and comprehensive for us. The authors are not experts in the IS designing. The BSP method observes the business process as both a source and a user of information. The information flow contains data classes.

Our business processes are:

- updating curricula,

- enrolment of the academic/school year,

- enrolment of the study year,

- registering of subjects in each semester,

- fee payment,

- tuition delivery,

- examinations,

- semester verification,

- degree issuing .

Data classes are

- study programme,

- student's high school degree and entrance examination results,

- study group,

- students' registered subjects in each semester,

- tuition fee,

- students' evidence,

- examination reports,

- student records,

- graduated student record. 
Now we can create relationships matrix showing relationships between processes and classes.

Table 1: Relationships of business processes and data classes

\begin{tabular}{|c|c|c|c|c|c|c|c|c|c|}
\hline $\begin{array}{l}\text { Data } \\
\text { Classes } \\
\text { Process }\end{array}$ & 冚 & 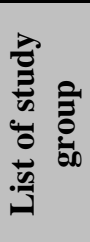 & $\begin{array}{l}\frac{n}{0} \\
\frac{0}{0} \\
\frac{0}{2} \\
\frac{0}{0}\end{array}$ & 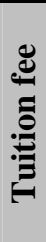 & 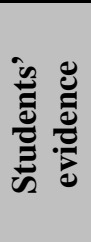 & 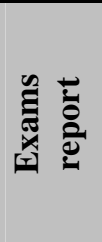 & 苛 & 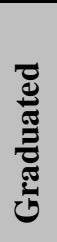 & 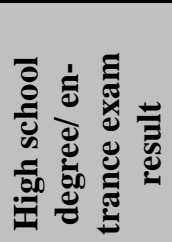 \\
\hline $\begin{array}{l}\text { Updating cur- } \\
\text { ricula }\end{array}$ & $\mathrm{C}$ & & & & & & & & \\
\hline $\begin{array}{l}\text { Enrolment of a } \\
\text { school year }\end{array}$ & & $\mathrm{C}$ & & & & $\mathrm{U}$ & & & $\mathrm{U}$ \\
\hline $\begin{array}{l}\text { Enrolment of a } \\
\text { study year }\end{array}$ & $\mathrm{U}$ & $\mathrm{C}$ & & & & $\mathrm{U}$ & & & \\
\hline $\begin{array}{l}\text { Registering } \\
\text { subjects in a } \\
\text { semester }\end{array}$ & $\mathrm{U}$ & $\mathrm{U}$ & $\mathrm{C}$ & & & $\mathrm{U}$ & & & \\
\hline Fee payments & $\mathrm{U}$ & $\mathrm{U}$ & $\mathrm{U}$ & $\mathrm{C}$ & & & & & \\
\hline $\begin{array}{l}\text { Tuition deliv- } \\
\text { ery }\end{array}$ & $\mathrm{U}$ & $\mathrm{U}$ & $\mathrm{U}$ & & $\mathrm{C}$ & & & & \\
\hline Examinations & $\mathrm{U}$ & $\mathrm{U}$ & $\mathrm{U}$ & & & $\mathrm{C}$ & & & \\
\hline $\begin{array}{l}\text { Semester veri- } \\
\text { fication }\end{array}$ & $\mathrm{U}$ & $\mathrm{U}$ & $\mathrm{U}$ & & & $\mathrm{U}$ & $\mathrm{C}$ & & \\
\hline Degree issuing & $\mathrm{U}$ & $\mathrm{U}$ & & & & $\mathrm{U}$ & & $\mathrm{C}$ & \\
\hline
\end{tabular}

In the above matrix, the note $\mathrm{C}$ indicates that data classes are created through the particular process, while the note $\mathrm{U}$ means that data classes are used by processes.

Table 2: Relationships of business processes and organization units

\begin{tabular}{|l|c|c|c|c|c|c|c|}
\hline \multicolumn{1}{|c|}{ Organiz. } & $\begin{array}{c}\text { Depart- } \\
\text { ments }\end{array}$ & $\begin{array}{c}\text { Register } \\
\text { office }\end{array}$ & $\begin{array}{c}\text { Finance } \\
\text { department }\end{array}$ & Tuition & $\begin{array}{c}\text { Head of } \\
\text { Dept. }\end{array}$ & $\begin{array}{c}\text { Pro-Dean } \\
\text { for teaching }\end{array}$ & Dean \\
\hline Updating curricula & $\mathrm{X}$ & & & & & $\mathrm{X}$ & $\mathrm{X}$ \\
\hline $\begin{array}{l}\text { Enrolment of a } \\
\text { school year }\end{array}$ & & $\mathrm{X}$ & & & & $\mathrm{X}$ & $\mathrm{X}$ \\
\hline $\begin{array}{l}\text { Enrolment of a } \\
\text { study year }\end{array}$ & $\mathrm{X}$ & $\mathrm{X}$ & & & & & \\
\hline $\begin{array}{l}\text { Registering sub- } \\
\text { jects in a semester }\end{array}$ & $\mathrm{X}$ & $\mathrm{X}$ & & & & & \\
\hline Fee payments & & $\mathrm{X}$ & $\mathrm{X}$ & & & \\
\hline Tuition delivery & & $\mathrm{X}$ & & $\mathrm{X}$ & & & \\
\hline Examinations & & $\mathrm{X}$ & & & & $\mathrm{X}$ \\
\hline $\begin{array}{l}\text { Semester verifica- } \\
\text { tion }\end{array}$ & & $\mathrm{X}$ & & & $\mathrm{X}$ & & $\mathrm{X}$ \\
\hline Degree issuing & & & & & & \\
\hline
\end{tabular}


Table 2 shows which organization unit within the School takes part in performing the processes.

The organization units' usage of data classes is shown in Table 3.

Table 3: Relationships of data classes and organization units

\begin{tabular}{|c|c|c|c|c|c|c|c|}
\hline $\begin{array}{l}\text { Org. units } \\
\text { Classes }\end{array}$ & Department & $\begin{array}{c}\text { Register } \\
\text { office }\end{array}$ & $\begin{array}{c}\text { Finance } \\
\text { depart- } \\
\text { ment }\end{array}$ & Tuition & $\begin{array}{c}\text { Head of } \\
\text { Dept. }\end{array}$ & \begin{tabular}{|c} 
Pro- \\
Dean for \\
teaching
\end{tabular} & Dean \\
\hline $\begin{array}{l}\text { Study pro- } \\
\text { gramme }\end{array}$ & $\mathrm{X}$ & $\mathrm{X}$ & & $\mathrm{X}$ & & $\mathrm{X}$ & $\mathrm{X}$ \\
\hline $\begin{array}{l}\text { List of study } \\
\text { group }\end{array}$ & $\mathrm{X}$ & $\mathrm{X}$ & & & & $\mathrm{X}$ & \\
\hline Courses list & & $\mathrm{X}$ & & $\mathrm{X}$ & & $X$ & \\
\hline Tuition fee & & $\mathrm{X}$ & $\mathrm{X}$ & & & & $\mathrm{X}$ \\
\hline $\begin{array}{l}\text { Students' evi- } \\
\text { dence }\end{array}$ & & $X$ & & $X$ & & & \\
\hline $\begin{array}{l}\text { Exams } \\
\text { report }\end{array}$ & & $\mathrm{X}$ & & & & $\mathrm{X}$ & \\
\hline $\begin{array}{l}\text { Student's re- } \\
\text { cord }\end{array}$ & & $X$ & & & & & \\
\hline Graduated & & $X$ & & & $X$ & & $\mathrm{X}$ \\
\hline $\begin{array}{l}\text { High school } \\
\text { degree/ en- } \\
\text { trance exam } \\
\text { result }\end{array}$ & & $X$ & & & & $X$ & X \\
\hline
\end{tabular}

\section{Identifying the Information Needs}

Identifying the information needs is the key step in system analysis. Identified information needs will define the system performances. The following questions should be included in this analysis:

- Which decisions are made regularly?

- Which information is necessary to make decisions?

- Which information is received really?

- Which information should be received?

- Which special analyses are required?

- Which area is information coming from?

- Which useful improvements can be made in the current IS?

Logical projecting includes modeling of both the processes and the data. Processes modeling describe the future system state with data movement and processing. Data modeling gives conceptual data models expressing the real system. These models should be understandable and acceptable for users as well as the project authors and those not related to the following project phases.

The physical project is a logical project realization the basis on the chosen resources. System documentation is the final step of the project analysis and design (Mihajlovic, 1998). 


\section{Structured System Analysis (SSA)}

Structured system analysis is the process of modeling and documenting the data requirements of the system. In this analysis, we use data flow diagram (DFD) and data dictionary.

Data flow diagram is a graphical representation of the data flow for visualization of data processing. At the first stage, a context-level DFD, i.e. the highest-level view of the system and its inputs and outputs from/to external entities is drawn. It is then decomposed to show more details.

(Pfleeger \& Atlee, 2006)

Data dictionary consists of data flow, elementary data, data storage and primitive processes. It contains descriptions and representations of data elements. It is a set of tables and views involving:

- Definition of data elements,

- Usernames, roles and privileges,

- Schemes of objects,

- Integrity constraints,

- Stored procedures and triggers,

- General database structure,

- Space allocation.

\section{Data Flow Diagram}

Hierarchical decomposition of DFD allows a higher-level process to be decomposed into lowerlevel processes until the decomposition has a common sense, i.e. until the level of primitive processes, which cannot be decomposed further. In our case the highest level, context level DFD, is the whole IS within the study area in our Institution. It consists of several high-level processes (Figure 4) as well as their communication (inputs and outputs) (Veljovic, 2003).

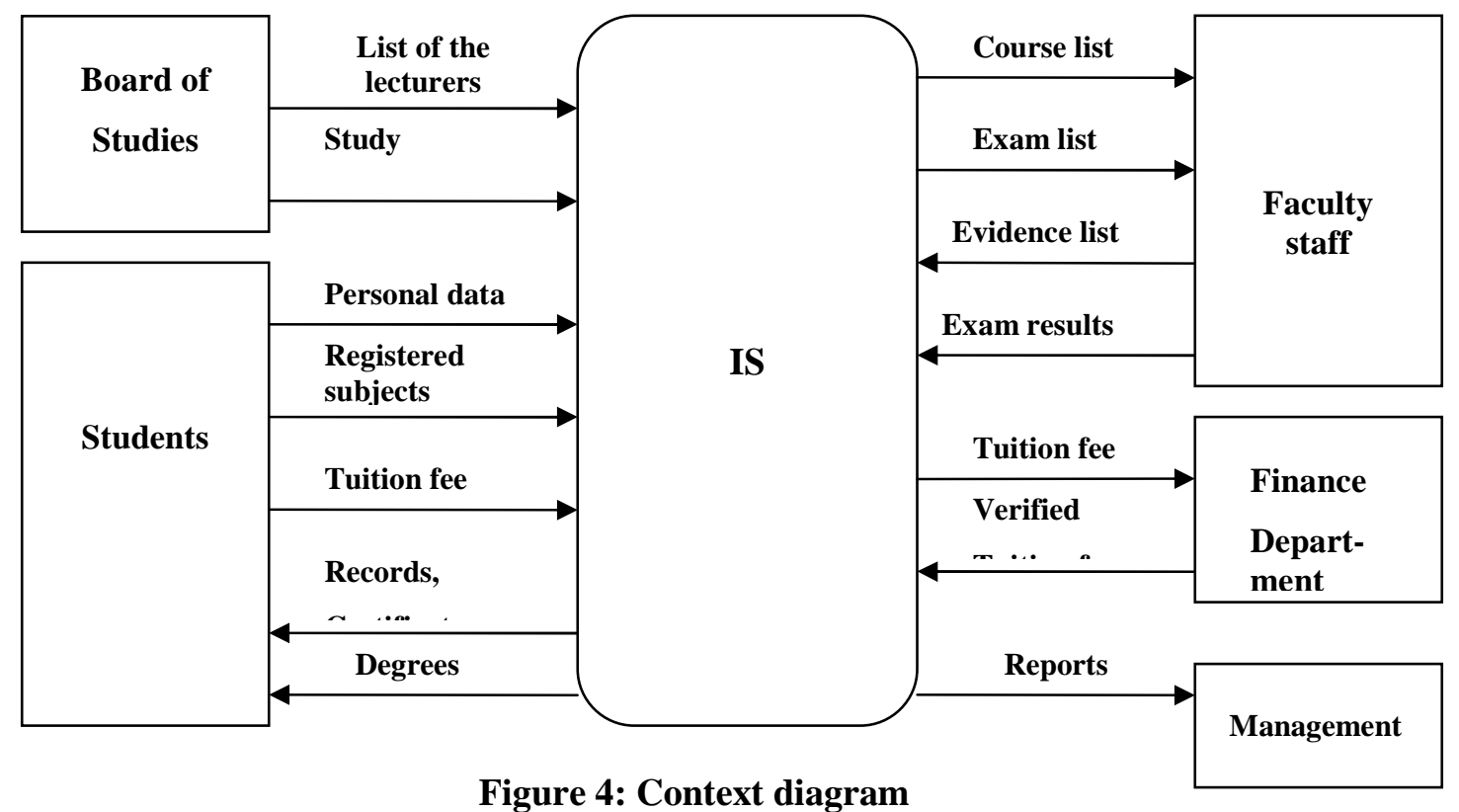


In this case, the context diagram consists of:

- One process (the zero-level School information system)

- Five external elements - Board of studies, students, faculty staff, finance department, and management,

- Data flow between the external elements and the process.

The decomposition process splits the context diagram into the first level diagram. Lower level processes are denoted as A1, A2, A3 ... and at the following level as A1.1, A1.2,.., A2.1, A $2.2, \ldots$ according to the decomposition process.

At level 1, there are three processes (Figure 5): potential students' application process, teaching process and payments.

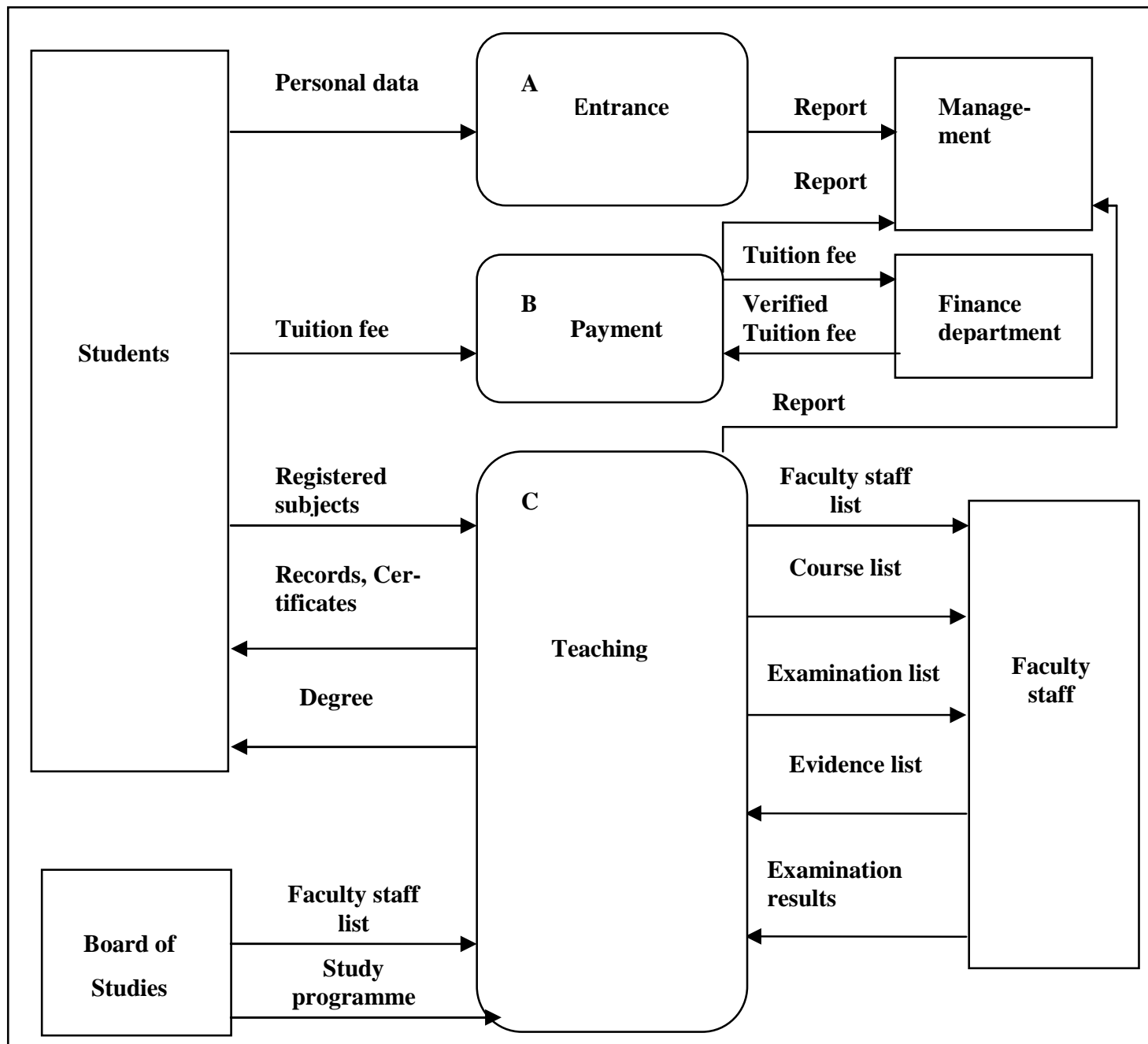

Figure 5: Diagram of level 1

The application of potential new students is performed once or twice per year and it can be decomposed into two processes:

- application and entrance examination (A1),

- ranking and enrolment (A2). 
The payment process divides into the payment of:

- application and entrance examination (B1),

- tuition fees (B2).

The Board of Studies prepares inputs for those processes and the management receives reports about it. Those processes are at the second level and they are primitive processes, i.e. their further decomposition would not be reasonable.

The teaching process is decomposed into several processes with possibilities of further decomposition:

- $\quad$ students enrolment $(\mathrm{C} 1)$

○ enrolment of academic/school year (C1.1),

$\circ$ registering the subjects $(\mathrm{C} 1.2)$,

- semester verification (C1.3), which becomes student's record for the completed semester and defines the study year on the basis of accumulated credits.

○ enrolment of study year (C1.4), that offers possibilities for registering corresponding subjects.

- tuition (C2)

○ updating curricula and syllabi (C2.1),

○ tuition delivery (C.2.2), which beside lectures involves students evidence and fulfilling conditions for taking a particular exam.

- examination $(\mathrm{C} 3)$

○ applying for exams (C3.1),

○ assessment (C3.2).

- $\quad$ issuing students documentation (C4)

$\circ$ issuing records $(\mathrm{C} 4.1)$,

○ issuing certificates (C4.2),

○ issuing the final diploma (C4.3).

We will not illustrate all diagram levels, only the zero-level (Figure 4) and the level 1 (Figure 5). Additionally, Figure 6 presents hierarchy of the decomposed IS. 


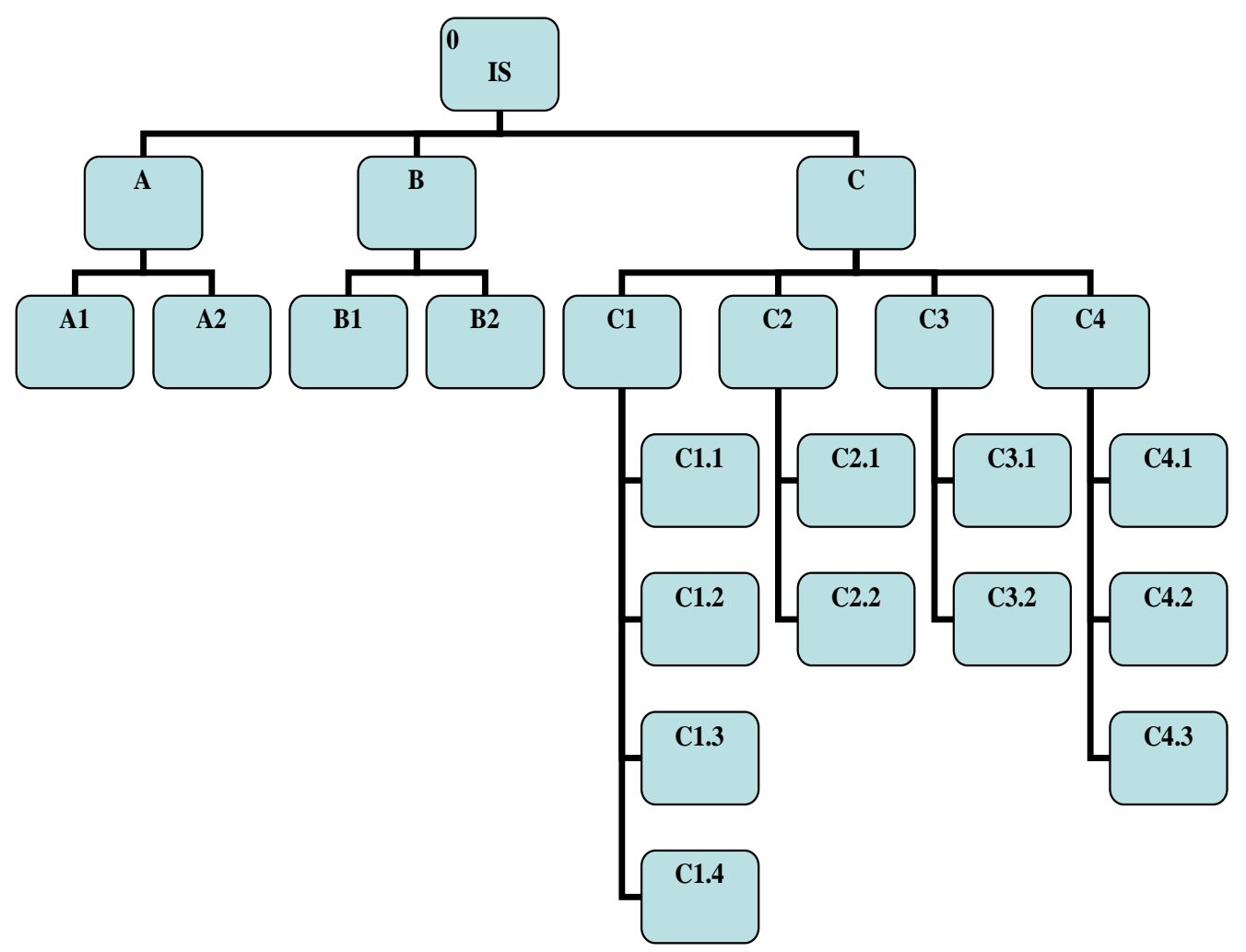

Figure 6: Hierarchical decomposition of the IS

\section{Data Dictionary}

Our focus is the general database structure. IS should be provided by following databases:

- Master databases,

- Modified databases,

- Derived databases,

- Control databases,

- Output databases.

Master databases are:

- Study programme database with keywords and names of the study programmes,

- Students database, with student personal data, date of enrolments into academic and study years, student status (self- or Government-financed),

- Subjects database with keywords and names of subjects, allocated credits, and lecturer names,

- Password database with access control,

- Graduated students' database with completed students records,

○ Database of ex students. 
Modified databases are:

- Registered subjects database with keywords of subjects and lists of students registered for those subjects,

- Examination database with data about examinations in regular examination periods.

Derived databases are:

- Database of passed examinations with data about students' examination results and the numbers of attempts in taking every exam,

○ Database for evidence of students' all passed exams.

Control databases are:

- Database of students applied for entrance examinations,

- Payment of entrance examination,

○ Payment of tuition fees for self-financed students.

Output databases are:

- List of students registered for subjects, applied to examinations in a particular exam period, etc.

- Students record about registered the subjects and examination results per each semester.

Details about databases fields, attributes, and their domain are outside the scope of this paper. Our current IS has almost all above mentioned databases and their content will be modified in certain parts.

\section{Flow Diagram}

In this section, a brief flow diagram of our IS (Figure 7) is illustrated. This diagram includes overall procedures, input and output documents.

Figure 8 depicts a part of the enrolment in study years due to conditions complexity. 


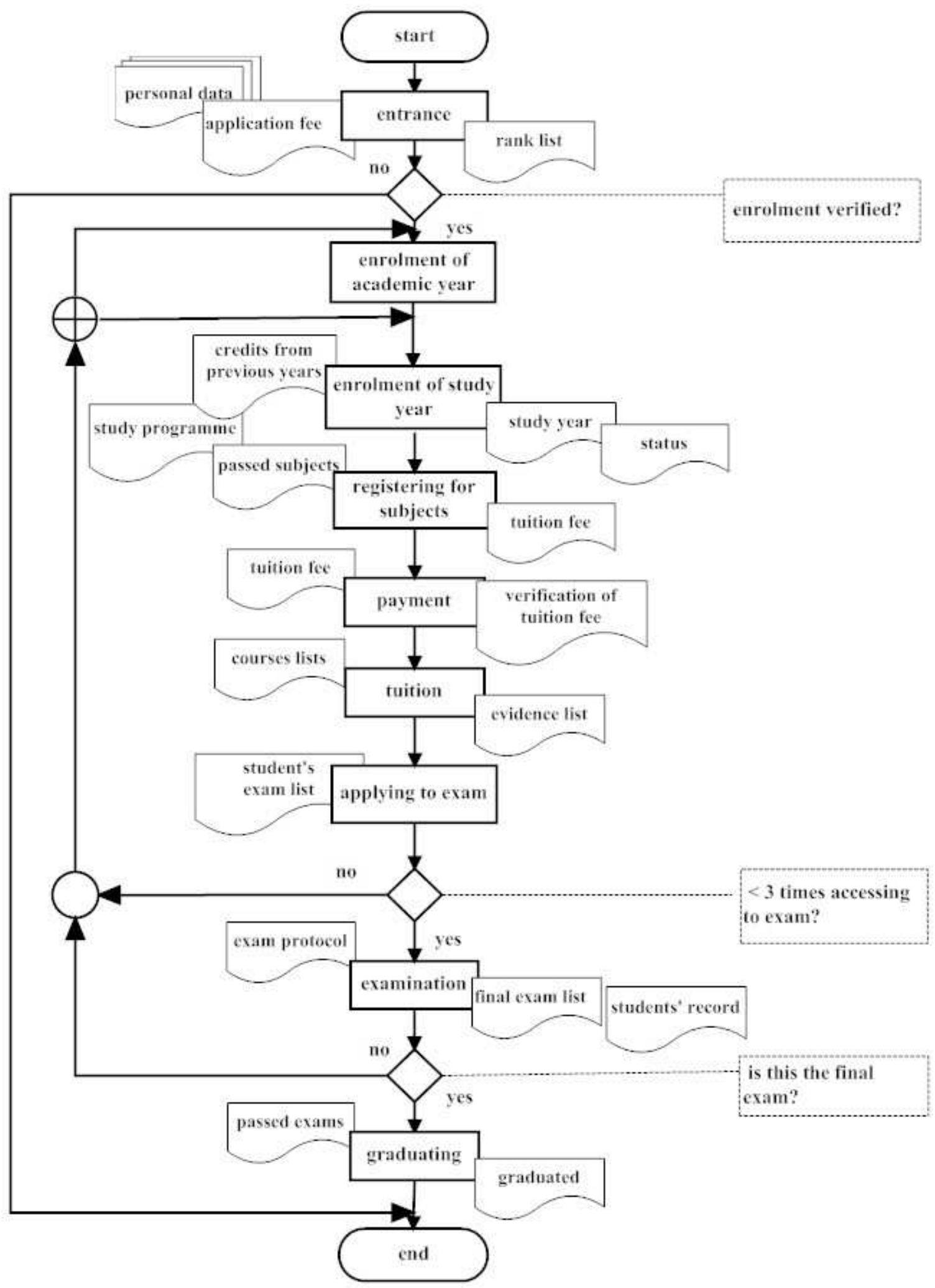

Figure 7: Flow diagram 


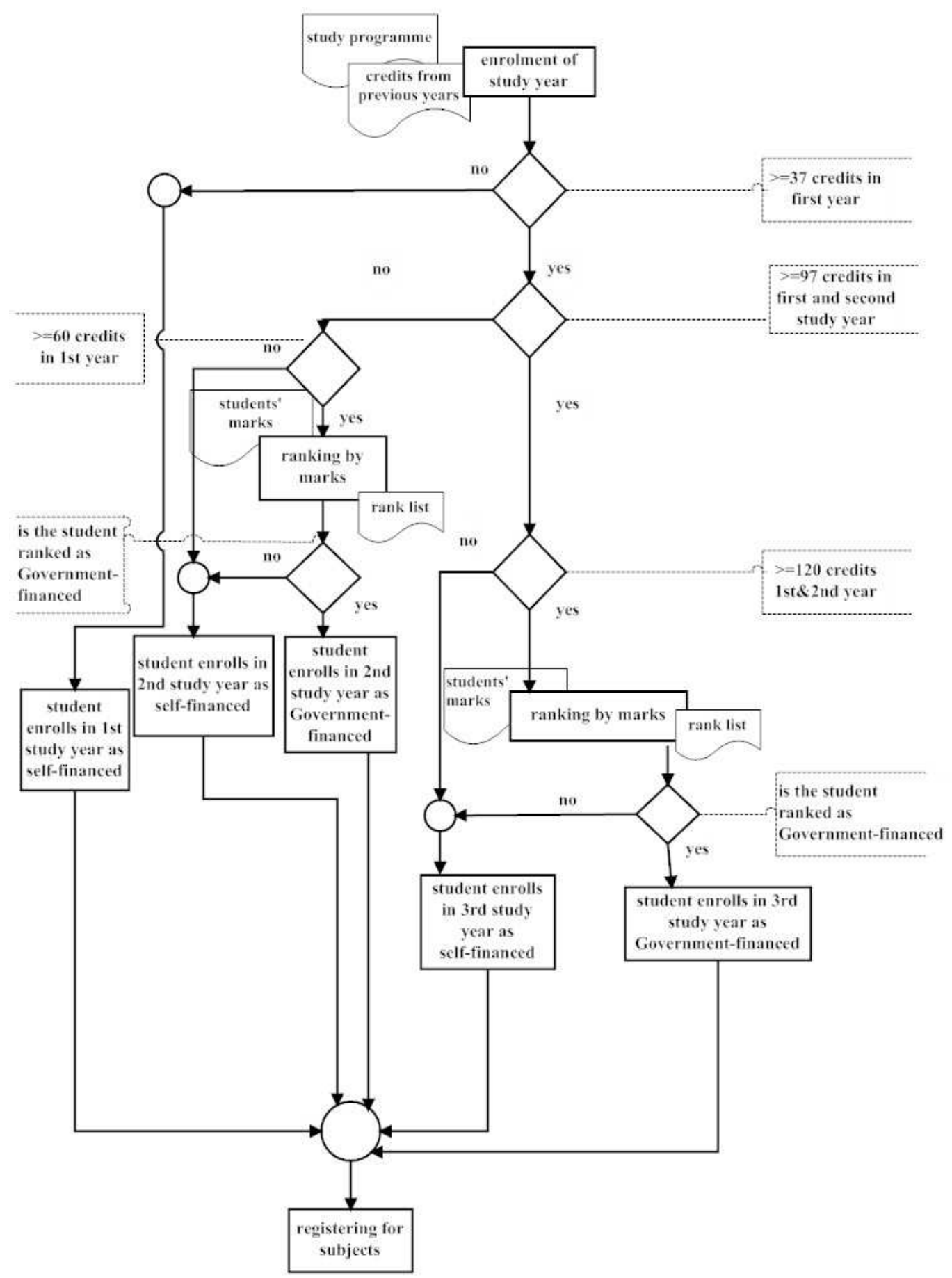

Figure 8: Conditions of the enrolment of study year 


\section{Conclusion}

Due to a lack of relevant evaluation of the system applied the goal of this paper is not to raise the topic to the scientific level, but to present it as a practical experience.

Although the authors have not had a practical experience in IS projecting, their intentions was to try this. Through the engagement in updating curricula and syllabi according to the Bologna Declaration they felt that the new regulations might bring a lot of challenges for educational system in the School.

As there were no detailed directives from the Government about applying the new educational system, we hope that exchanging personal experiences would be very helpful. Writing of this paper enabled us to articulate the comprehension of an IS to be designed for the new study rules. We expect that our work will be improved. Our IT lecturers, with a team of IT students, will finalize this project and implement it.

This will help us to put into practice a better system of education. The IS organized in this way will itself induce teachers to use it. They will have to create and update data according to the system requirements. The next paper of the same authors will discuss assessments of the efficiency regarding the applied IS.

\section{References}

Amberg, M. (1996). A pattern-oriented approach to a methodical evaluation of modeling methods. Australian Journal of Information Systems, 1(4), 3-10.

Davenport, T., H., \& Prusak, L. (1997). Working knowledge: How organizations manage what they know. Harvard Business School Press

Demeyer S. \& Bosh, J. (Eds.). (1998). Object-Oriented Technology. ECOOP'98 Workshop Reader, ECOOP'98 Workshop Demos and Poster, Brussels, Belgium

Drucker, P. F. (1999a). Beyond the information revolution. The Atlantic Monthly, 284(4), 47-57.

Drucker, P. F. (1999b). Management challenges for the 21st century. New York: Harper Business, A Division of Harper Collins Publishers.

Gates, B. (2001) Business @ the Speed of Thought. New York: Warner Books.

Koulopoulos, T. M. (1997). Smart companies, smart tools: Transforming business processes into business assets. Van Nostrad Reinhold, A Division of International Thompson Publishing.

Lindsay, J. (2006). Information systems - Fundamentals and issues. Kingston University, UK

Lovrekovic, Z., Ruzic-Dimitrijevic, L., \& Nikolic, B. (2007). Information system implementation based on process approach at higher education institutions. Proceedings of the Computer Science and IT Education Conference, CSITEd 2007, Mauritius. Retrieved from http://csited.org/2007/90LovrCSITEd.pdf

Mihajlovic, D. (1998). Information system and data base project. University in Novi Sad.

Pfleeger, S. L., \& Atlee, J. M. (2006). Software engineering theory and practise. Pearson Education.

Prince, T. R. (1971). Information systems for management planning and control. Georgetown, Ontario: Irwin - Dorsey Limited,

Veljovic, A. (2003). Projecting information systems. Cacak: Computer Bibliotheca. 


\section{Biographies}

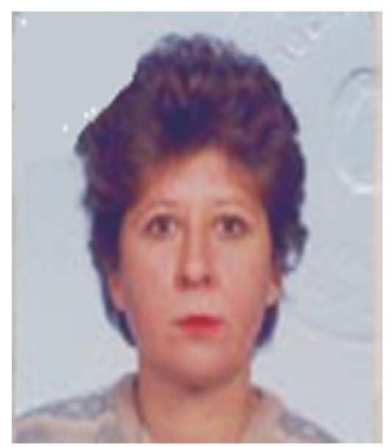

Ljiljana Ružić-Dimitrijević is a professor at the Higher Education Technical School of Professional Studies, Novi Sad, Serbia. She teaches courses in Computers, Introduction to web design, and Development of the Internet. She got her MSc degree in mathematics at the Center of Multidisciplinary Studies, Belgrade in 1991. Her field of expertise is computer graphics and web design. She is pro-dean in charge of tuition.

Bozo Nikolic is a professor at the Higher Education Technical School of Professional Studies, Novi Sad, Serbia. He teaches courses in the fields of mechanical engineering and labor safety. He got his $\mathrm{PhD}$ degree in mechanical engineering at the Belgrade University in 1998. His areas of expertise are tools, accessories, and risk assessment regarding workplace and workspace. He is director of the Higher Education Technical School of Professional Studies. 